\title{
'n Ondersoek na die Behoefte aan en die Houdings Teenoor Voortgesette Onderwys by Geregistreerde Verpleegkundiges Werksaam by die Tygerberg-Hospitaal
}

Isabel M. Hofmeyr B.Sc., D.Ed. Departement Verpleegkunde, Universiteit van Stellenbosch

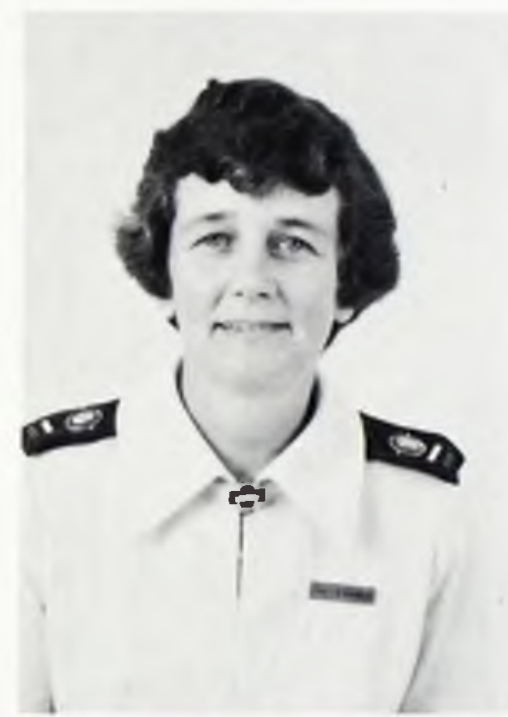

\section{SUMMARY}

The need for and attitude towards continuing education of $\mathbf{4 0 3}$ registered nurses at the Tygerberg Hospital were assessed by means of a questionnaire. Subjects in which the need for continuing education was felt were identified and a programme has been instituted in which continuing education by means of active participation in group work has been instituted.

G

EDURENDE Maart en April 1978 is 'n ondersoek uitgevoer om die houdings van geregistreerde verpleegkundiges by die Tygerberg-hospitaal teenoor voortgesette onderrig te probeer bepaal. Deur middel van " $n$ vraelys is aan hulle die geleentheid gebied om ook hul behoeftes in hierdie verband te stel. Die regstreekse aanleiding tot die ondersoek was 'n driedaagse seminaar oor voortgesette onderwys wat in Junie in die Fakulteit van Geneeskunde van die Universiteit van Stellenbosch gehou is. Die uitslag van hierdie ondersoek is verder ook as referaat voorgedra by die Akademiese Jaardag van die Fakulteit.

Daar is 450 vraelyste uitgestuur aan die blanke en ge-
Ir -urde geregistreerde verpleegkundiges van die Tygerperg-hospitaal en deur bemiddeling van die matrones is 403 antwoorde terug ontvang. Die verhouding van poste op die diensstaat is 2 poste vir blankes vir elke een pos vir 'n gekleurde geregistreerde verpleegkundige. Van die 403 vraelyste wat terug ontvang is, was $279(69.2 \%)$ van blankes en $116(28,8 \%)$ van gekleurdes. Daar was 'n groot ouderdomsverskil in die groep: $24 \%$ van die groep was tussen 20 en 24 jaar oud terwyl 2,1\% van die groep tussen 55 en 59 jaar oud was, met "n gemiddelde ouderdom van 30,4 jaar.

Die onderwyskwalifikasies waaroor die respondente beskik, word in tabel 1 aangetoon: 
TABEL I

SKOOLSTANDERD BEHAAL

\begin{tabular}{l|c|c|c|c}
\hline & \multicolumn{2}{|c|}{ Blankes } & \multicolumn{2}{c}{ Gekleurdes } \\
\hline & Aantal & $\%$ & Aantal & $\%$ \\
\hline Std. 8 & 35 & 12.7 & 71 & 61.2 \\
Std. 9 & 10 & 3.6 & 8 & 6.9 \\
Std. 10 & 231 & 83.7 & 37 & 31.9 \\
\hline
\end{tabular}

Geen respons:

11 persone.

Die beroepskwalifikasies van die respondente word in tabel 2 weergegee:

TABEL II

KWALIFIK ASIES

\begin{tabular}{|l|r|r|}
\hline & & \\
& AANT AL & \multicolumn{1}{c|}{$\%$} \\
\cline { 2 - 3 } Algemeen & 401 & 99.5 \\
Verloskunde & 330 & 81.9 \\
Psigiatrie & 25 & 6.2 \\
Pediatrie & 5 & 1.2 \\
Teater & 30 & 7.4 \\
Intensief & 25 & 6.2 \\
Oogheelkunde & 2 & 0.5 \\
Ortopedie & 3 & 0.7 \\
Volksgesondheid & 8 & 2.0 \\
Onderwys & 11 & 2.7 \\
Administrasie & 27 & 6.7 \\
Ander & 23 & 5.7 \\
& & \\
Geen respons: 2 persone. & & \\
Algemeen & & \\
Algemeen en Verloskunde & 69 & 18.4 \\
Algemeen en Psigiatrie & 329 & 81.6 \\
Algemeen. Verloskunde en Psigiatrie & 3 & 0.7 \\
Algemeen. Verloskunde en Administrasie & 22 & 5.5 \\
Algemeen, Verloskunde en Onderwys & 26 & 6.5 \\
Algemeen. Verloskunde. Onderwys en Administrasie & 11 & 2.7 \\
\end{tabular}

Van die respondente het $38,7 \%$ tussen 0 en 4 jaar tevore hul basiese opleiding voltooi en 'n verdere $29,0 \%$ tussen 5 en 9 jaar terwyl 2,2\% meer as 30 jaar gelede hul basiese opleiding voltooi het. Die gemiddelde aantal jare na voltooiing was 8,4 jaar. Dertig persent van die groep het ' $n$ onderbreking in diens gehad wat gewissel het tussen 1 en 25 jaar.

Die area van verpleging waar die persone werksaam was ten tye van die ondersoek word in tabel 3 aangedui. 'n Interessante aspek wat hier na vore gekom het. is dat die persone wat in eenhede vir intensiewe sorg werk hulleself nie ingedeel het onder die afdelings vir interne geneeskunde. chirurgie e.s.m. nie maar wel onder die hoof: Ander. Van die 40 I persone wat hierdie vraag beantwoord het, beklee 37 of $9.4 \%$ die een of ander matrone-pos. 57 of $14.1 \%$ is senior susters terwyl die res $(76,2 \%)$ sustersposte beklee. 
TABEL III

WERKPLEK

\begin{tabular}{|l|c|r|}
\hline & AANTAL & \multicolumn{1}{|c|}{$\%$} \\
\cline { 2 - 3 } Interne & 47 & 11.7 \\
Chirurgie & 69 & 17.1 \\
Pediatrie & 22 & 5.5 \\
Verloskunde & 65 & 16,1 \\
Teater & 73 & 18.1 \\
Administrasie & 7 & 1.7 \\
Buite-pasiënte & 26 & 6.5 \\
Klinies & 13 & 3.2 \\
Ander & 80 & 19.9 \\
\hline
\end{tabular}

Geen respons: 1

$\mathrm{V}$ an die respondente was 91 persone $(22,3 \%)$ in die jaar waaroor die ondersoek gegaan het, besig met verdere studie.

Die aard daarvan word in tabel 4 aangetoon.

TABEL IV

AARD VAN STUDIE

\begin{tabular}{|c|c|c|c|c|c|}
\hline \multicolumn{3}{|c|}{ VOLTYDS } & \multicolumn{3}{|c|}{ DEELTYDS } \\
\hline & Aantal & $\%$ & & Aantal & $\%$ \\
\hline $\begin{array}{l}\text { Verloskunde } \\
\text { Intensief } \\
\text { Teater } \\
\text { Pediatrie }\end{array}$ & $\begin{array}{r}19 \\
9 \\
19 \\
2\end{array}$ & $\begin{array}{l}4.7 \\
2.2 \\
4.7 \\
0.5\end{array}$ & $\begin{array}{l}\text { Verpl. graad } \\
\text { Ander graad } \\
\text { Matriek } \\
\text { Ander }\end{array}$ & $\begin{array}{r}16 \\
6 \\
17 \\
2\end{array}$ & $\begin{array}{l}4,0 \\
1,5 \\
4,2 \\
0,5\end{array}$ \\
\hline
\end{tabular}

Vir die doel van hierdie ondersoek is voortgesette onderwys gedefinieer as daardie studie en onderrig wat 'n geregistreerde verpleegkundige moet deurmak om op hoogte te bly van ontwikkelings in haar beroep om sodoende te help om gesondheidsdienste te verbeter. Dit sou bv. kon insluit individuele studie in Verpleegkunde wat na-uurs gedoen word, studie ter voorbereiding van ' $n$ lesing. of lesings/demonstrasies oor nuwe ontwikkelings wat bygewoon word deur verpleegk undiges wat lank gelede hul opleiding voltooi het. Verkieslik behoort dit volgens 'n gestruk- tureerde en goedbeplande program te geskied. Lesings oor bv. brandbestryding in 'n spesifieke hospitaal of oor die gebruik van die kommunikasiestelsel word beskou as oriëntasie in " $n$ bepaalde inrigting en nie voortgesette onderwys nie.

Vier-en-negentig persent van die respondente het verklaar dat voortgesette onderwys vir hulle as verpleegkundiges nodig is. Die menings oor wie se verantwoordelikheid dit is, in wie se tyd dit moet geskied en wie die koste daarvan moet dra. word aangetoon in tabel 5 .

TABEL V

VERANTWOORDELIKHEID

\begin{tabular}{l|c|c|c|c}
\hline & Opleidingskool & Werkgewer & Self & Beide \\
\cline { 2 - 5 } Totaal & $8.7 \%$ & $8,4 \%$ & $10,4 \%$ & $69,0 \%$ \\
Blankes & $6.9 \%$ & $8,8 \%$ & $10,2 \%$ & $74,1 \%$ \\
Gekleurdes & $14,8 \%$ & $8,3 \%$ & $12,1 \%$ & $64.8 \%$ \\
\hline
\end{tabular}

Onvolledig:

21 persone 
In wie se tyd?

\begin{tabular}{l|c|c|c}
\hline & Vrye tyd & Dienstyd & $1 / 2$ Diens \\
& $1 / 2$ Vry \\
\cline { 2 - 4 } Totaal & $3.2 \%$ & $59.8 \%$ & $32.5 \%$ \\
Blankes & $2.6 \%$ & $64.3 \%$ & $33.1 \%$ \\
Gekleurdes & $5.5 \%$ & $56.9 \%$ & $37.6 \%$ \\
\hline
\end{tabular}

Onvolledig: 22 persone

Wie dra koste?

\begin{tabular}{l|c|c|c}
\hline & Self & Werkgewer & Beide \\
\cline { 2 - 4 } Totaal & $4.5 \%$ & $41.2 \%$ & $49.4 \%$ \\
Blankes & $5.2 \%$ & $41.5 \%$ & $53.3 \%$ \\
Gekleurdes & $3.7 \%$ & $46.8 \%$ & $49.5 \%$ \\
\hline
\end{tabular}

Onvolledig: $\quad 24$ persone

Op die vraag hoeveel persone die afgelope jaar voortgesette onderwys benut het. het $57.3 \%$ bevestigend geantwoord. Van hierdie groep het $79 \%$ dit wat aangebied was, as baie waardevol of uiters waardevol bestempel. Die persone wat dit nie benut het nie het as rede daarvoor o.a. aangegee dat dit nie beskikbaar was nie, dat hulle nie geïnteresseerd daarin was nie, dat hulle nie tyd daarvoor ingeruim het nie en dat hulle besig was met voltydse kursusse.
Daar is aan die respondente die geleentheid gebied om vyf onderwerpe of terreine te noem waarop hulle voel dat hulle "n behoefte aan voortgesette onderwys uitgespreek het. was daar 111 persone wat nie van hierdie geleentheid gebruik gemaak het nie. Die onderwerpe wat versoek is deur meer as 10 van die 268 persone word weergegee in tabel 6 . Hierbenewens is " $n$ verskeidenheid van onderwerpe deur minder as 10 persone versoek

\section{TABEL VI \\ ONDERWERPE VERSOEK DEUR 268 PERSONE}

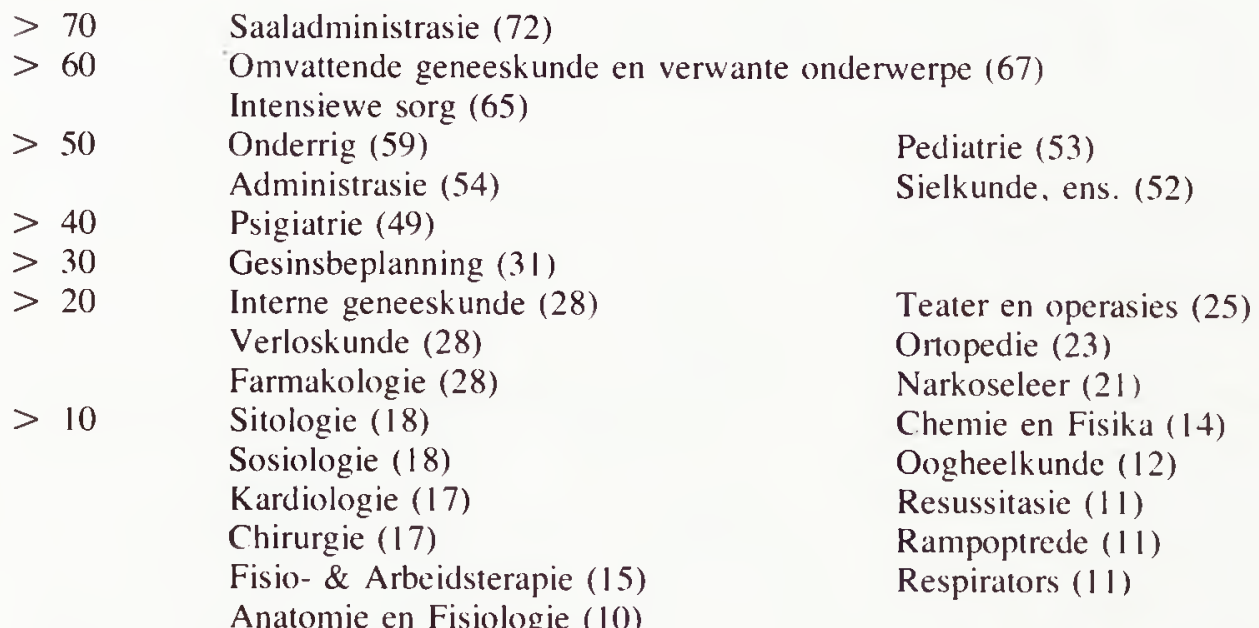

In 'n poging om 'n korrelasie te kry tussen die jare na voltooiing van basiese opleiding en die versoeke vir Saaladministrasie is gevind dat $34,7 \%$ van die versoeke gekom het van persone met 2 jaar ondervinding na basiese opleiding en die persentasie het gestyg tot $61,1 \%$ vir persone met 5 jaar ondervinding of minder. Die inligting wat op hierdie wyse verkry is, is teruggevoer na die hoofmatrone en matrones van die hospitaal. Omdat ons van mening is dat " $n$ persoon alleen leer deur self aktief besig te wees, is daar aan 'n teikengroep van 20 matrones die metode van werk in klein groepe gedemonstreer deur aan hulle praktiese vraagstukke uit die hospitaalsituasie te stel. Hulle antwoorde en oplossings is tydens vier sessies van 2 uur elk voorgedra en die voorneme is nou dat hulle die metode aan geregistreerde verpleegkundiges wat volgens hulle belangstellings en werkterreine ingedeel is, sal uitdra. 